Article

\title{
Copper Aluminum Spinels Doped with Cerium as Catalysts for NO Removal
}

\author{
Anna Białas ${ }^{1, * \mathbb{D}}$, Kamil Rugała ${ }^{1}$, Cezary Czosnek ${ }^{1}$, Grzegorz Mordarski ${ }^{2}$ and Jacek Gurgul ${ }^{2} \mathbb{D}$ \\ 1 AGH University of Science and Technology, Faculty of Energy and Fuels, al. Mickiewicza 30, \\ PL-30059 Kraków, Poland; kamrug95@gmail.com (K.R.); czosnek@agh.edu.pl (C.C.) \\ 2 Jerzy Haber Institute of Catalysis and Surface Chemistry, Polish Academy of Sciences, Niezapominajek 8, \\ PL-30239 Kraków, Poland; nbmordar@cyf-kr.edu.pl (G.M.); ncgurgul@cyf-kr.edu.pl (J.G.) \\ * Correspondence: anbialas@agh.edu.pl; Tel.: +48-32-617-2115
}

Received: 28 October 2020; Accepted: 27 November 2020; Published: 28 November 2020

\begin{abstract}
Cu}-\mathrm{Ce}(\mathrm{Mn})-\mathrm{Al}$ oxide catalysts to $\mathrm{NO}$ removal in the broad temperature range were synthesized and tested. The precursor of copper aluminium spinel was obtained with the coprecipitation method. By this method, $\mathrm{Cu}-\mathrm{Al}$ spinels with various amounts of manganese and cerium were synthesized as well. These oxides crystallized in the structure of inverse spinel; however, $\mathrm{Ce}$ doping caused the appearance of additional $\mathrm{CeO}_{2}$ phase as determined by XRD. The samples were mesoporous solids with moderate surface area and porosity measured by low temperature sorption of nitrogen. The addition of another metal to $\mathrm{Cu}-\mathrm{Al}$ spinel caused an increase of activity in selective catalytic reduction of nitrogen oxide with ammonia. The presence of manganese caused the formation of a higher amount of $\mathrm{N}_{2} \mathrm{O}$ by-product. The catalytic activity increased with the cerium concentration. For the sample with the atomic ratio $\mathrm{Ce}_{0.15} \mathrm{Cu}_{0.18}, \mathrm{ca} .90 \%$ of $\mathrm{NO}$ conversion was registered between 200 and $350^{\circ} \mathrm{C}$. As examined with XPS spectroscopy, such conversion was attained due to the good dispersion of copper on the catalyst surface. This copper was placed mainly in spinel octahedral positions which enable its easier reduction. The spinel structure causes the presence of cerium as the trivalent cation important in redox cycles with the participation of copper.
\end{abstract}

Keywords: coprecipitation; spinel; aluminate; ceria; copper catalyst; NO removal; SCR

\section{Introduction}

Nitrogen oxides $\left(\mathrm{NO}_{\mathrm{x}}\right)$ are one of the main air pollutants that form during fuel burning. Their Selective Catalytic Reduction (SCR) with ammonia is applied to remove them from off-gases from the stationary sources of emission [1]. During this process, nitrogen and water are expected products like in the following reactions:

$$
\begin{gathered}
4 \mathrm{NO}+4 \mathrm{NH}_{3}+\mathrm{O}_{2} \rightarrow 4 \mathrm{~N}_{2}+6 \mathrm{H}_{2} \mathrm{O}, \\
6 \mathrm{NO}+4 \mathrm{NH}_{3} \rightarrow 5 \mathrm{~N}_{2}+6 \mathrm{H}_{2} \mathrm{O} .
\end{gathered}
$$

Unfortunately, nitrous oxide is often formed as well, according to the reaction equations:

$$
\begin{gathered}
3 \mathrm{NO} \rightarrow \mathrm{N}_{2} \mathrm{O}+\mathrm{NO}_{2}, \\
2 \mathrm{NH}_{3}+2 \mathrm{O}_{2} \rightarrow \mathrm{N}_{2} \mathrm{O}+3 \mathrm{H}_{2} \mathrm{O}, \\
4 \mathrm{NO}+4 \mathrm{NH}_{3}+3 \mathrm{O}_{2} \rightarrow 4 \mathrm{~N}_{2} \mathrm{O}+6 \mathrm{H}_{2} \mathrm{O} \\
4 \mathrm{NO}_{2}+4 \mathrm{NH}_{3}+\mathrm{O}_{2} \rightarrow 4 \mathrm{~N}_{2} \mathrm{O}+6 \mathrm{H}_{2} \mathrm{O} .
\end{gathered}
$$


This greenhouse gas influences the global warming about 300 hundred times stronger than carbon dioxide. Its lifetime in atmosphere is ca. 180 years and can be decomposed only in the stratosphere according to the reaction equation:

$$
\mathrm{N}_{2} \mathrm{O}+\mathrm{O}_{3} \rightarrow 2 \mathrm{NO}+\mathrm{O}_{2} \rightarrow 2 \mathrm{NO}_{2}
$$

Ozone is taken from the ozone layer damaging Earth's protection [2]. The amount of nitrous oxide emitted from anthropogenic sources has increased and now is assessed as $40 \%$ of total $\mathrm{N}_{2} \mathrm{O}$ emission [3]. Therefore, in order to design catalysts for SCR of NOx, it is important to remember their high selectivity to avoid forming this by-product. Such catalysts can be obtained by the deposition of an active phase on a support or by its coprecipitation with metal ions improving its properties.

Coprecipitation is regarded as a simple synthesis method of industrial catalysts [4]. The oxide catalysts obtained by this method turned out to be efficient in SCR of $\mathrm{NO}_{x}$ due to the good dispersion of an active phase, its high concentration [5], as well as a strong interaction between active metals [6]. In such systems, aluminum oxide has often been the dispersive phase. Moreover, its acidic properties also improve resistance to sulfur poisoning [6]. The aluminum oxide often crystallizes with other metals in the spinel structure [5,7]. It was suggested that the spinel structure can be responsible for the high catalytic activity of copper-aluminum oxide systems in SCR of NO [7]. It is related to the large adsorption of NO due to the high number of oxygen vacancies $[1,6]$. The spinel composition can be designed in such a way to obtain the catalyst active in a broad temperature range of $100-400{ }^{\circ} \mathrm{C}$ [8]. In automotive catalysts, the alumina support is promoted with ceria, which can store oxygen, develop their surface area, and improve thermal stability. The key factor in the $\mathrm{CeO}_{2}$ efficiency is its dispersion [4]. The lattice oxygen of ceria takes part in the oxidation reaction, and the reduced oxide is reoxidized by $\mathrm{NO}$ or $\mathrm{N}_{2} \mathrm{O}$ with the formation of nitrogen without $\mathrm{N}_{2} \mathrm{O}$ production [1]. $\mathrm{CeO}_{2}$ inhibits also the formation of $\mathrm{NH}$ species, which are intermediates of $\mathrm{N}_{2} \mathrm{O}$ [6]. Cerium and copper can form a redox system which inhibits $\mathrm{SO}_{2}$ oxidation or can form sulfates protecting the active copper centers and can accelerate its decomposition as well [6]. Ceria also inhibits the formation of ammonium nitrate and protects the catalyst from the alkali poisoning providing the Lewis acid sites for $\mathrm{NH}_{3}$ activation [6].

The aim of the presented paper was to obtain a copper aluminum spinel catalyst and then to modify its catalytic properties by substituting a part of copper by cerium and/or manganese. The relationship between the sample catalytic activity in SCR of NO with ammonia and the amount of cerium was examined. Factors determining the catalytic activity were identified by a physicochemical characterization of solids.

\section{Results and Discussion}

Obtained copper-aluminium oxide and its derivatives doped with cerium and manganese (0.03 and 0.06 atomic ratio) were subjected to catalytic tests in SCR of NO with ammonia (Figure 1). For all samples, the NO conversion was in the range $20-40 \%$ at $150{ }^{\circ} \mathrm{C}$, attained its maximum at 250 or $300{ }^{\circ} \mathrm{C}$, and decreased below $40 \%$ at $450{ }^{\circ} \mathrm{C}$. Over the $\mathrm{Cu}_{0.33}$ sample, the maximum of $\mathrm{NO}$ conversion of ca. $85 \%$ was observed at $300{ }^{\circ} \mathrm{C}$. The replacement of copper by cerium in the $\mathrm{Ce}_{0.03} \mathrm{Cu}_{0.30}$ sample caused a slight increase in the catalytic efficiency at lower temperatures $\left(150-250^{\circ} \mathrm{C}\right)$ and a more distinct decrease above $400^{\circ} \mathrm{C}$. The analogous substitution with manganese brought about an increase in $\mathrm{NO}$ conversion in the whole temperature range. The mixed $\mathrm{Mn}_{0.03} \mathrm{Ce}_{0.03} \mathrm{Cu}_{0.27}$ sample was less efficient than that with manganese but slightly better than with cerium one, particularly at higher temperatures of $400-450{ }^{\circ} \mathrm{C}$. The increase in manganese content did not strengthen the catalytic efficiency. In contrast, the same increase in the cerium concentration caused improvement in the catalyst activity making the $\mathrm{Ce}_{0.06} \mathrm{Cu}_{0.27}$ sample only slightly less active than the $\mathrm{Mn}_{0.03} \mathrm{Cu}_{0.30}$ sample at low temperatures of $150-200^{\circ} \mathrm{C}$. 

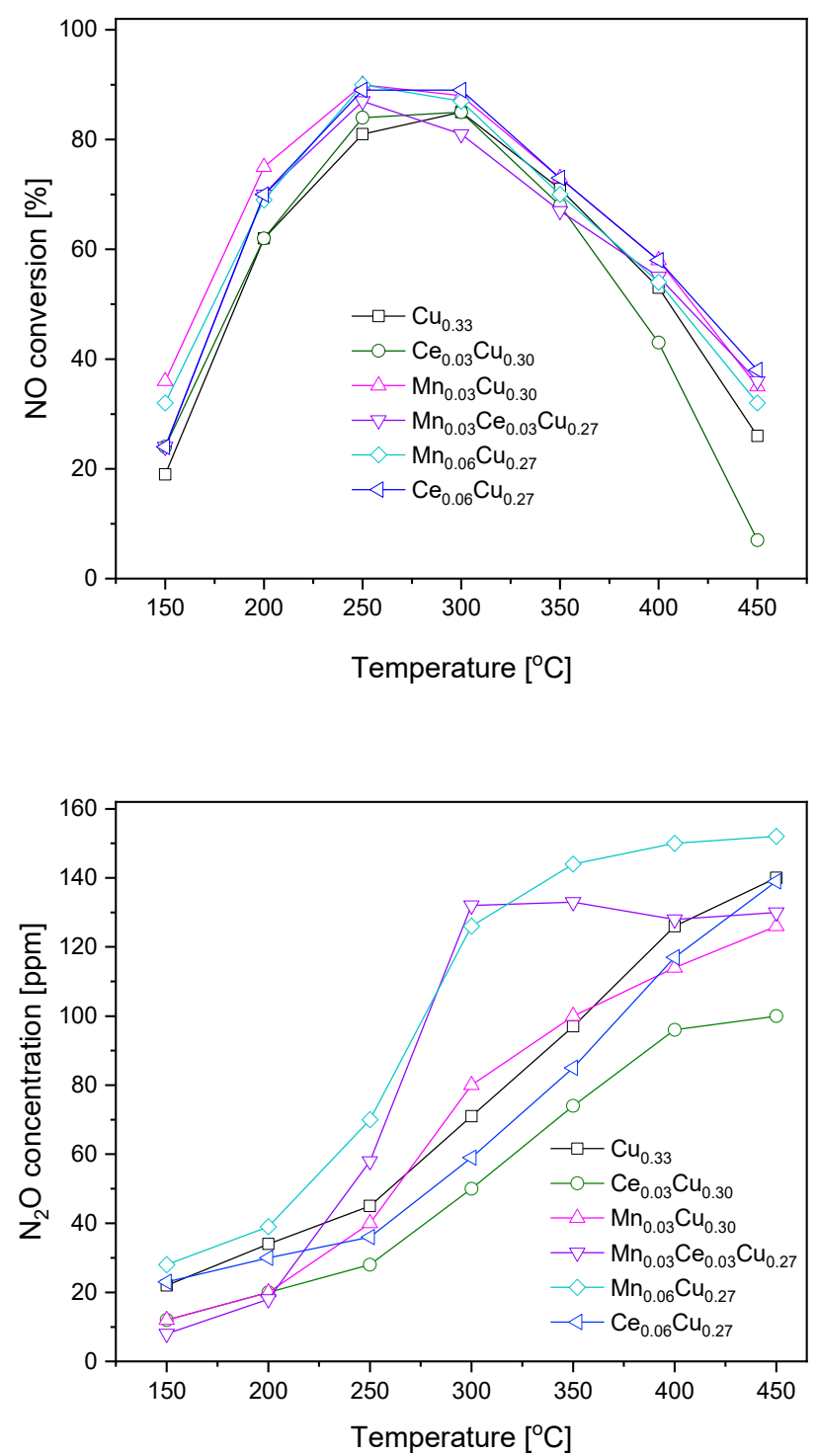

Figure 1. $\mathrm{NO}$ conversion and $\mathrm{N}_{2} \mathrm{O}$ formation over $\mathrm{Cu}-\mathrm{Al}$ catalysts doped with manganese and cerium.

During the catalytic tests, the concentration of $\mathrm{N}_{2} \mathrm{O}$ forming the undesired by-product was measured as well (Figure 1). Over the undoped catalyst, the concentration of $\mathrm{N}_{2} \mathrm{O}$ achieved $45 \mathrm{ppm}$ at $250{ }^{\circ} \mathrm{C}$ and started to rise more rapidly above this temperature reaching a level of $140 \mathrm{ppm}$ at $450{ }^{\circ} \mathrm{C}$. The admixture of Ce resulted in significant lowering of $\mathrm{N}_{2} \mathrm{O}$ formation, namely, at $300{ }^{\circ} \mathrm{C}$, the $\mathrm{N}_{2} \mathrm{O}$ concentration exceeded the detection limit of $30 \mathrm{ppm}$ and reached $100 \mathrm{ppm}$ at $450{ }^{\circ} \mathrm{C}$. In the temperature range of $300-350{ }^{\circ} \mathrm{C}$, the presence of manganese increased the formation of by-product in comparison to the $\mathrm{Cu}_{0.33}$ sample; however, at higher temperatures $\left(400-450{ }^{\circ} \mathrm{C}\right)$, the opposite was true. The equimolar $\mathrm{Ce}_{0.03} \mathrm{Mn}_{0.03} \mathrm{Cu}_{0.27}$ catalyst caused the formation of $60 \mathrm{ppm}$ of nitrous oxide at $250{ }^{\circ} \mathrm{C}$, while above $300{ }^{\circ} \mathrm{C}$, the concentration of $\mathrm{N}_{2} \mathrm{O}$ was constant at the level of $130 \mathrm{ppm}$. The increase of the $\mathrm{Mn}$ amount resulted in the highest $\mathrm{N}_{2} \mathrm{O}$ concentration in the whole temperature range. In the case of higher cerium content, the amount of $\mathrm{N}_{2} \mathrm{O}$ formed was about $10 \mathrm{ppm}$ higher than over the $\mathrm{Ce}_{0.03} \mathrm{Cu}_{0.30}$ sample up to $350^{\circ} \mathrm{C}$.

To determine the crystallographic structure of catalysts, powder XRD patterns were registered as seen in Figure 2. For the $\mathrm{Cu}_{0.33}$ sample, the diffraction lines at a $2 \theta$ angle of ca. 19.0, 31.2, 36.9, $44.9,49.2,55.8,59.4,65.2,74.2,77.4,78.5$, and $82.7^{\circ}$ can be ascribed to (111), (220), (311), (400), (331), (422), (511), (440), (620), (533), (622), and (444) planes of $\mathrm{CuAl}_{2} \mathrm{O}_{4}$ spinel, respectively [01-071-0967]. Main reflections are narrow, which suggests that crystallites were rather large. Their average size was 
estimated based on the (311) plane from the Scherrer equation as equal to $31 \mathrm{~nm}$ (Table 1). After an admixture of cerium, new reflections at a $2 \theta$ angle of ca. 28.6, 33.1, 47.5, 56.3, 69.5, 76.7, and 88.5 appear, which origin from (111), (200), (220), (311), (400), (331), and (422) planes of $\mathrm{CeO}_{2}$, respectively [03-065-2975]. At the same time, the average crystallite size decreased to $21 \mathrm{~nm}$. The double increase in the cerium content did not change the $\mathrm{CeO}_{2}$ crystallite size (calculated for the (111) plane) in contrast to a noticeable decrease of spinel crystallite size to $18 \mathrm{~nm}$ (Table 1). In the case of manganese doping, only reflections from the spinel phase are present. It suggests that $\mathrm{Mn}$ formed a solid solution with copper-aluminum oxide in the spinel structure or an amorphous oxide. Manganese admixture caused a decrease of the average crystallite size to $18 \mathrm{~nm}$ in the $\mathrm{Mn}_{0.03} \mathrm{Cu}_{0.30}$ sample and to $21 \mathrm{~nm}$ in the $\mathrm{Mn}_{0.06} \mathrm{Cu}_{0.27}$ one. The doubly doped sample $\mathrm{Ce}_{0.03} \mathrm{Mn}_{0.03} \mathrm{Cu}_{0.27}$ crystallized in the spinel structure, although some cerium oxide was also detected. It seems that manganese ions have built into the spinel phase as well. The ceria crystallites were about $12 \mathrm{~nm}$ large and the spinel ones were ca. $20 \mathrm{~nm}$.

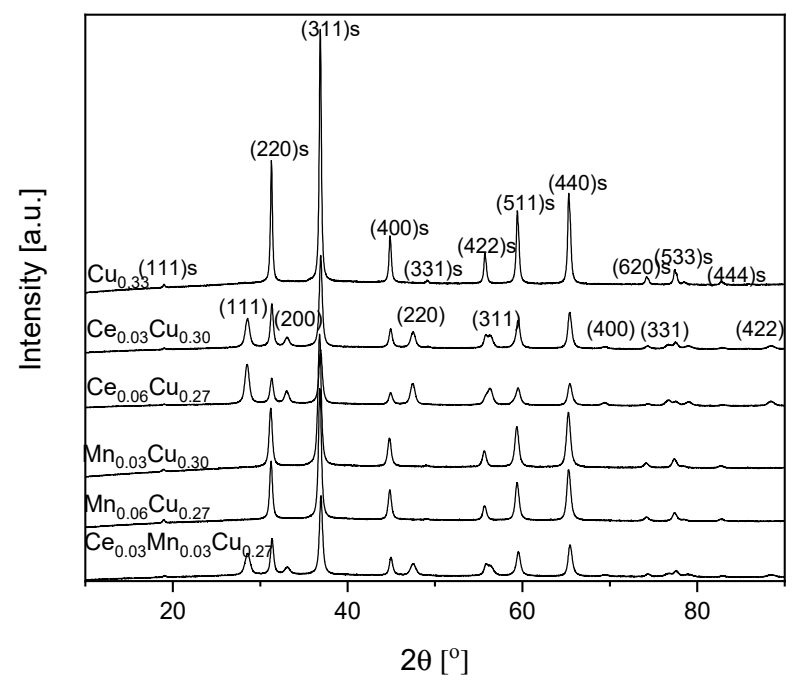

Figure 2. XRD patterns of $\mathrm{Cu}-\mathrm{Al}$ catalysts doped with manganese and cerium. The reflexes coming from the pure spinel structure are marked by ' $s$ '.

Table 1. Composition, crystallite sizes, and textural properties of $\mathrm{Ce}$ - and $\mathrm{Mn}$-doped $\mathrm{Cu}-\mathrm{Al}$ spinel catalysts.

\begin{tabular}{|c|c|c|c|c|c|}
\hline \multicolumn{2}{|c|}{ Sample } & \multicolumn{2}{|c|}{ Crystallite Size [nm] } & \multirow{2}{*}{$\begin{array}{l}\mathrm{SSA}_{\mathrm{BET}} \\
{\left[\mathrm{m}^{2} / \mathrm{g}\right]}\end{array}$} & \multirow{2}{*}{$\begin{array}{l}\text { Total Pore Volume } \\
{\left[\mathrm{cm}^{3} / \mathrm{g}\right]}\end{array}$} \\
\hline Nominal Formula & Real Formula & $(311) \mathrm{s}$ & (111) $\mathrm{CeO}_{2}$ & & \\
\hline $\mathrm{Cu}_{0.33}$ & $\mathrm{Cu}_{0.33}$ & 31 & - & 19 & 0.445 \\
\hline $\mathrm{Ce}_{0.03} \mathrm{Cu}_{0.30}$ & $\mathrm{Ce}_{0.03} \mathrm{Cu}_{0.27}$ & 21 & 14 & 29 & 0.195 \\
\hline $\mathrm{Mn}_{0.03} \mathrm{Cu}_{0.30}$ & $\mathrm{Mn}_{0.03} \mathrm{Cu}_{0.30}$ & 18 & - & 35 & 0.174 \\
\hline $\mathrm{Ce}_{0.06} \mathrm{Cu}_{0.27}$ & $\mathrm{Ce}_{0.07} \mathrm{Cu}_{0.24}$ & 18 & 15 & 36 & 0.283 \\
\hline $\mathrm{Mn}_{0.06} \mathrm{Cu}_{0.27}$ & $\mathrm{Mn}_{0.06} \mathrm{Cu}_{0.29}$ & 21 & - & 35 & 0.095 \\
\hline $\mathrm{Ce}_{0.03} \mathrm{Mn}_{0.03} \mathrm{Cu}_{0.27}$ & $\mathrm{Ce}_{0.03} \mathrm{Mn}_{0.03} \mathrm{Cu}_{0.26}$ & 20 & 12 & 34 & 0.172 \\
\hline $\mathrm{Ce}_{0.09} \mathrm{Cu}_{0.24}$ & $\mathrm{Ce}_{0.10} \mathrm{Cu}_{0.21}$ & 17 & 15 & 25 & 0.304 \\
\hline $\mathrm{Ce}_{0.12} \mathrm{Cu}_{0.21}$ & $\mathrm{Ce}_{0.10} \mathrm{Cu}_{0.21}$ & 17 & 14 & 34 & 0.264 \\
\hline $\mathrm{Ce}_{0.15} \mathrm{Cu}_{0.18}$ & $\mathrm{Ce}_{0.16} \mathrm{Cu}_{0.18}$ & 15 & 17 & 44 & 0.348 \\
\hline
\end{tabular}

The chemical composition and textural properties of oxide catalysts are compared in Table 1. The measured metal contents for the first six samples were very close to the intended ones. The $\mathrm{Cu}_{0.33}$ sample exhibited a SSA BET of $19 \mathrm{~m}^{2} \mathrm{~g}^{-1}$ and a total pore volume of $0.445 \mathrm{~cm}^{3} \mathrm{~g}^{-1}$. The replacement of some copper by cerium or manganese resulted in an increase in the specific surface area and a decrease of pore volume. The doping with Ce (0.03) caused almost $50 \%$ growth in $\mathrm{SSA}_{\mathrm{BET}}$, whereas the same amount of Mn brought about almost a double increase in this value. The pore volume decreased 
above two times. Further increase in Mn and Ce content (to 0.06) did not result in a change of SSA The total pore volume decreased with manganese amount and increased with cerium concentration.

Taking into account that the $\mathrm{Ce}_{0.06} \mathrm{Cu}_{0.27}$ sample was only slightly less catalytically active than the $\mathrm{Mn}_{0.03} \mathrm{Cu}_{0.30}$ one at lower temperatures, the increase in Mn content did not improve catalytic efficiency, and less $\mathrm{N}_{2} \mathrm{O}$ was formed over cerium containing catalysts. We prepared some additional samples with a higher content of $\mathrm{Ce}$. Over such catalysts, $\mathrm{NO}$ conversion increased with the cerium content; simultaneously, $\mathrm{N}_{2} \mathrm{O}$ formation grew (Figure 3). The $\mathrm{NO}$ conversion at $150{ }^{\circ} \mathrm{C}$ was an exception where the sequence of catalyst activity was different. Below $250^{\circ} \mathrm{C}$, the concentration of nitrous oxide changed from 40 to $50 \mathrm{ppm}$. Above this temperature, the growth was faster and linearly achieved ca. $150 \mathrm{ppm}$ at $450^{\circ} \mathrm{C}$. The increase in nitrous oxide formation with Ce content was small for higher cerium concentrations. NO conversion and $\mathrm{N}_{2} \mathrm{O}$ formation over the $\mathrm{Ce}_{0.09} \mathrm{Cu}_{0.24}$ catalyst did not follow that trend. The $\mathrm{Ce}_{0.15} \mathrm{Cu}_{0.18}$ sample exhibited the highest catalytic activity in the whole range of tested temperatures attaining the maximum at $250-300{ }^{\circ} \mathrm{C}$ and a $\mathrm{NO}$ conversion above $80 \%$ in the temperature range of $200-350{ }^{\circ} \mathrm{C}$, this activity is worse at higher temperatures than observed for the zeolite catalyst containing copper-Cu-SSZ-13, which achieved such activity in the range of $175-450{ }^{\circ} \mathrm{C}$ [9]. The comparable efficiency was attained for copper-alumina coprecipitated in the presence of carbon nanotubes-CuAlLDOCNT, NO conversion higher than $80 \%$ was measured for the temperature range of $180-330{ }^{\circ} \mathrm{C}$ [10]. For this catalyst, selectivity to $\mathrm{N}_{2}$ was about $95 \%$. While for the zeolite materials, $\mathrm{N}_{2} \mathrm{O}$ yield, calculated as $\mathrm{Y}_{\mathrm{N} 2 \mathrm{O}}=\left(2 \mathrm{xc}_{\mathrm{N} 2 \mathrm{O}}\right) /\left(\mathrm{c}_{\mathrm{NO}} \mathrm{Nin}+\mathrm{c}_{\mathrm{NH} 3 \mathrm{in}}\right)$, was ca. $6-10 \%$ [9]. We estimated this value for our catalyst in the range of $7-11 \%$.
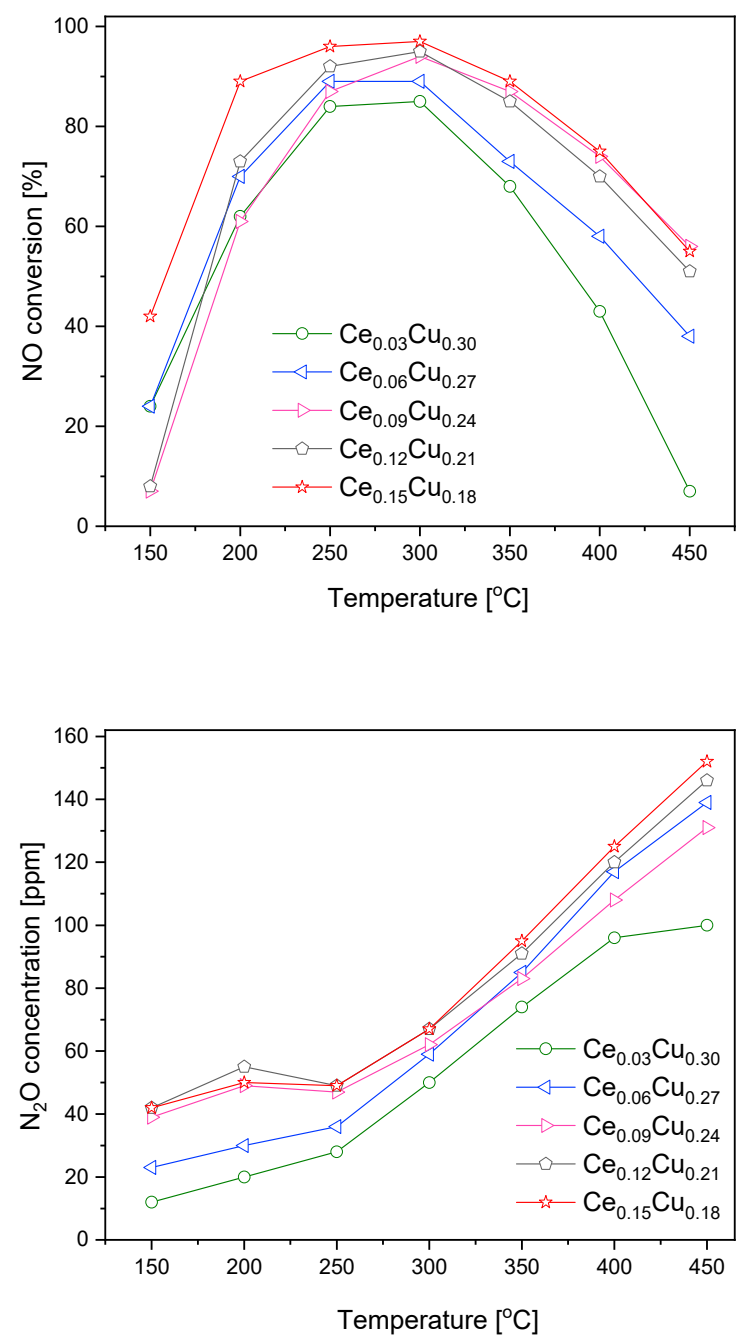

Figure 3. $\mathrm{NO}$ conversion and $\mathrm{N}_{2} \mathrm{O}$ formation over $\mathrm{Cu}-\mathrm{Al}$ catalysts doped with cerium. 
As seen from Table 1 and Figure 4, the average size of spinel crystallites decreased with the cerium content. Much weaker growth of spinel crystallites in the presence of ceria was described earlier [11]. On the other hand, the size of $\mathrm{CeO}_{2}$ crystallites remained almost the same. Only for the $\mathrm{Ce}_{0.15} \mathrm{Cu}_{0.18}$ sample a small increase in the crystallites size was observed. The metal concentration for the $\mathrm{Ce}_{0.09} \mathrm{Cu}_{0.24}$ and $\mathrm{Ce}_{0.12} \mathrm{Cu}_{0.21}$ samples were very similar, which could result from an experimental error during synthesis. The measured composition of the $\mathrm{Ce}_{0.15} \mathrm{Cu}_{0.18}$ catalyst was close to intended. The specific surface area lowered for the $\mathrm{Ce}_{0.09} \mathrm{Cu}_{0.24}$ sample to ca. $25 \mathrm{~m}^{2} \mathrm{~g}^{-1}$, and for the $\mathrm{Ce}_{0.12} \mathrm{Cu}_{0.21}$, catalyst remained similar as for the $\mathrm{Ce}_{0.06} \mathrm{Cu}_{0.27}$ sample. The total pore volume did not change significantly. The catalyst with the highest cerium content exhibited the largest SSA $\mathrm{BET}_{\mathrm{BET}}$ and a pore volume ca. $44 \mathrm{~m}^{2} \mathrm{~g}^{-1}$ and $0.348 \mathrm{~cm}^{3} \mathrm{~g}^{-1}$, respectively (Table 1 ).

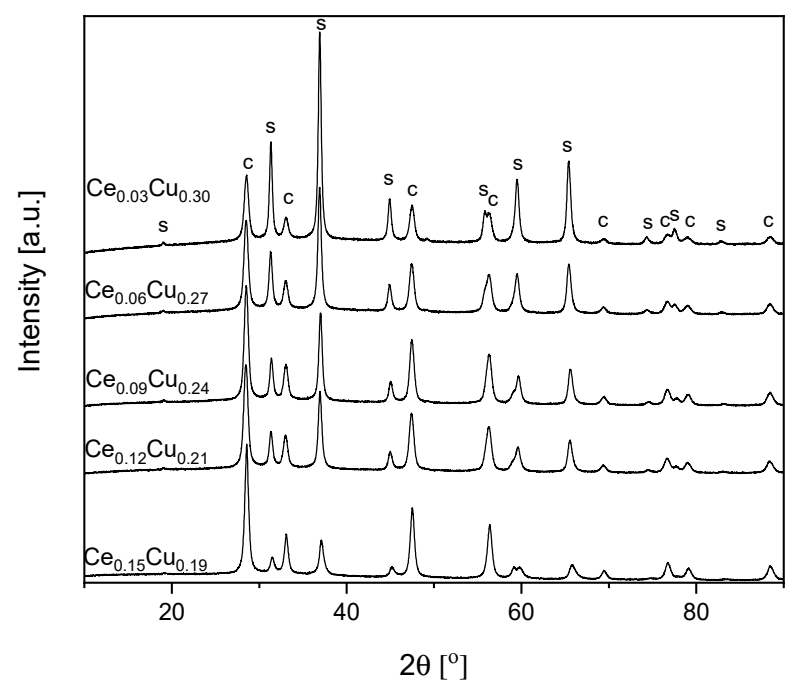

Figure 4. XRD patterns of $\mathrm{Cu}-\mathrm{Al}$ catalysts doped with cerium, 's' stands for spinel and ' $\mathrm{c}$ ' for $\mathrm{CeO}_{2}$.

To shed some light on the catalytic activity of copper aluminum spinel and the role of Ce dopant, the XPS measurements were taken for parent $\mathrm{Cu}_{0.33}$ and samples with various $\mathrm{Ce}$ contents before and after SCR of NO. The surface concentration of cerium and copper was calculated from the XPS survey spectra (Table 2). All samples were analyzed in detail in $\mathrm{O} 1 \mathrm{~s}, \mathrm{C} 1 \mathrm{~s}, \mathrm{Al} 2 \mathrm{p}, \mathrm{Cu} 2 \mathrm{p}$, and Ce $3 \mathrm{~d}$ regions.

Table 2. XPS Surface composition of cerium doped $\mathrm{Cu}-\mathrm{Al}$ spinels (at.\%).

\begin{tabular}{cccccc}
\hline Sample & $\mathbf{C e}$ & $\mathbf{C u}$ & $\mathbf{A l}$ & $\mathbf{O}$ & $\mathbf{C}$ \\
\hline $\mathrm{Cu}_{0.33}$ & - & 6.7 & 33.5 & 56.4 & 3.4 \\
$\mathrm{SCR}-\mathrm{Cu}_{0.33}$ & - & 6.9 & 30.9 & 57.0 & 5.2 \\
$\mathrm{Ce}_{0.03} \mathrm{Cu}_{0.30}$ & 0.7 & 7.1 & 31.7 & 56.8 & 3.7 \\
$\mathrm{SCR}-\mathrm{Ce}_{0.03} \mathrm{Cu}_{0.30}$ & 0.6 & 6.6 & 32.0 & 56.6 & 4.2 \\
$\mathrm{Ce}_{0.15} \mathrm{Cu}_{0.18}$ & 2.1 & 4.4 & 29.4 & 56.5 & 7.6 \\
$\mathrm{SCR}-\mathrm{Ce}_{0.15} \mathrm{Cu}_{0.18}$ & 0.6 & 5.4 & 33.6 & 56.8 & 3.6 \\
\hline
\end{tabular}

The O 1s spectra (Figure 5) were well-decomposed into three components: (i) a most intense peak (>60\%) located at 530.6-530.8 eV referred to the $\mathrm{O}^{2-}$ ions in the matrix of $\mathrm{CuAl}_{2} \mathrm{O}_{4}$ [12]; (ii) a small peak $(<3 \%)$ at $528.5-529.8 \mathrm{eV}$ due to oxygen-metal bonds ( $\mathrm{CuO}(528.6 \mathrm{eV}-529.8 \mathrm{eV})$ [13,14], $\mathrm{CeO}_{2}$ (528.7-529.2 eV) [15,16], $\mathrm{Al}_{2} \mathrm{O}_{3}(528.3-528.7 \mathrm{eV})$ ) [17]; (iii) a peak at $\mathrm{BE}$ of 531.7-531.8 eV assigned to $\mathrm{OH}$ groups, adsorbed water, and oxygen of organic contaminants. It can be seen from Table 3 that there are some small differences $(<5 \%)$ of relative amount of oxygen species between the fresh and used samples. However, one cannot exclude that these differences could be larger, but samples after the SCR reaction were stored under air atmosphere and could reoxidized before XPS studies. 


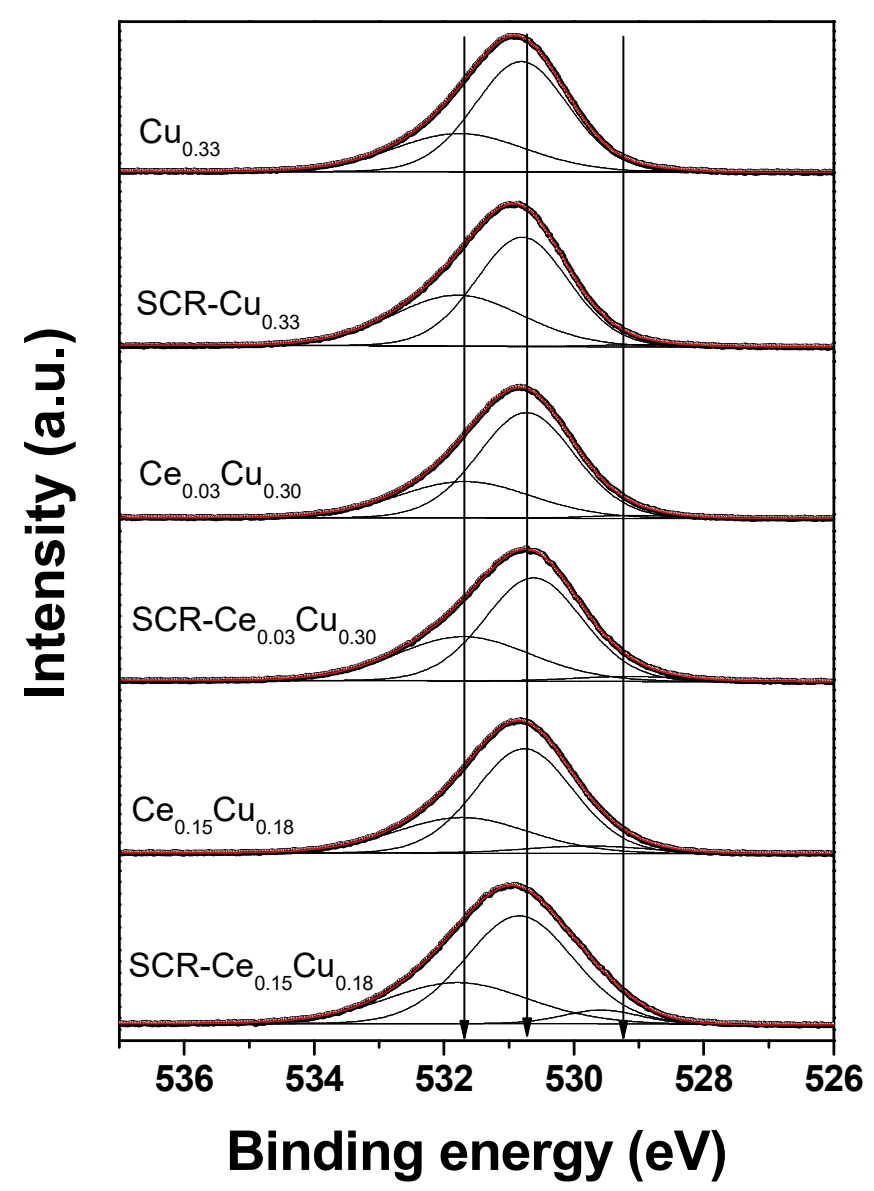

Figure 5. O 1s XPS spectra of $\mathrm{Cu}-\mathrm{Al}$ parent spinels and doped with cerium for fresh and used catalysts.

Table 3. Spectral fitting parameters for $\mathrm{O} 1 \mathrm{~s}$ : binding energy $(\mathrm{eV})$ and percentage of total area.

\begin{tabular}{cccc}
\hline Sample & Oxygen-Metal Bonds & $\mathbf{O}^{\mathbf{2}-}$ Ions in $\mathbf{C u A l}_{\mathbf{2}} \mathbf{O}_{\mathbf{4}}$ & OH Groups, Organic Contaminants \\
\hline $\mathrm{Cu}_{0.33}$ & 528.5 & 530.8 & 531.8 \\
& $(0.7)$ & $(66.7)$ & $(32.6)$ \\
$\mathrm{SCR}-\mathrm{Cu}_{0.33}$ & 528.9 & 530.8 & 531.8 \\
& $(1.4)$ & $(59.6)$ & $(39.0)$ \\
$\mathrm{Ce}_{0.03} \mathrm{Cu}_{0.30}$ & 529.1 & 530.7 & 531.7 \\
$\mathrm{SCR}-$ & $(1.8)$ & $(66.4)$ & $(31.8)$ \\
$\mathrm{Ce}_{0.03} \mathrm{Cu}_{0.30}$ & 529.1 & 530.6 & 531.7 \\
$\mathrm{Ce}_{0.15} \mathrm{Cu}_{0.18}$ & $(3.4)$ & $(60.7)$ & $(35.9)$ \\
$\mathrm{SCR}-\mathrm{Ce}_{0.15} \mathrm{Cu}_{0.18}$ & 529.6 & 530.8 & 531.8 \\
& $(5.5)$ & $(63.8)$ & $(30.7)$ \\
\end{tabular}

Three peaks at $285.0 \mathrm{eV}$ (organic contaminants), 285.8-286.0 eV (C-O groups), and 289.2-289.5 eV (O-C $=\mathrm{O}$ groups) can be distinguished in the $\mathrm{C} 1$ s spectra (Figure 6). The hydrocarbon contamination was used as an internal calibration for our insulating samples, as we mentioned below. The binding energy of the $\mathrm{Al} 2 \mathrm{p}_{3 / 2}$ core line is close to $74.1 \mathrm{eV}$ suggesting $\mathrm{Al}^{3+}$ in tetrahedral sites of the spinel structure [12,18]. 


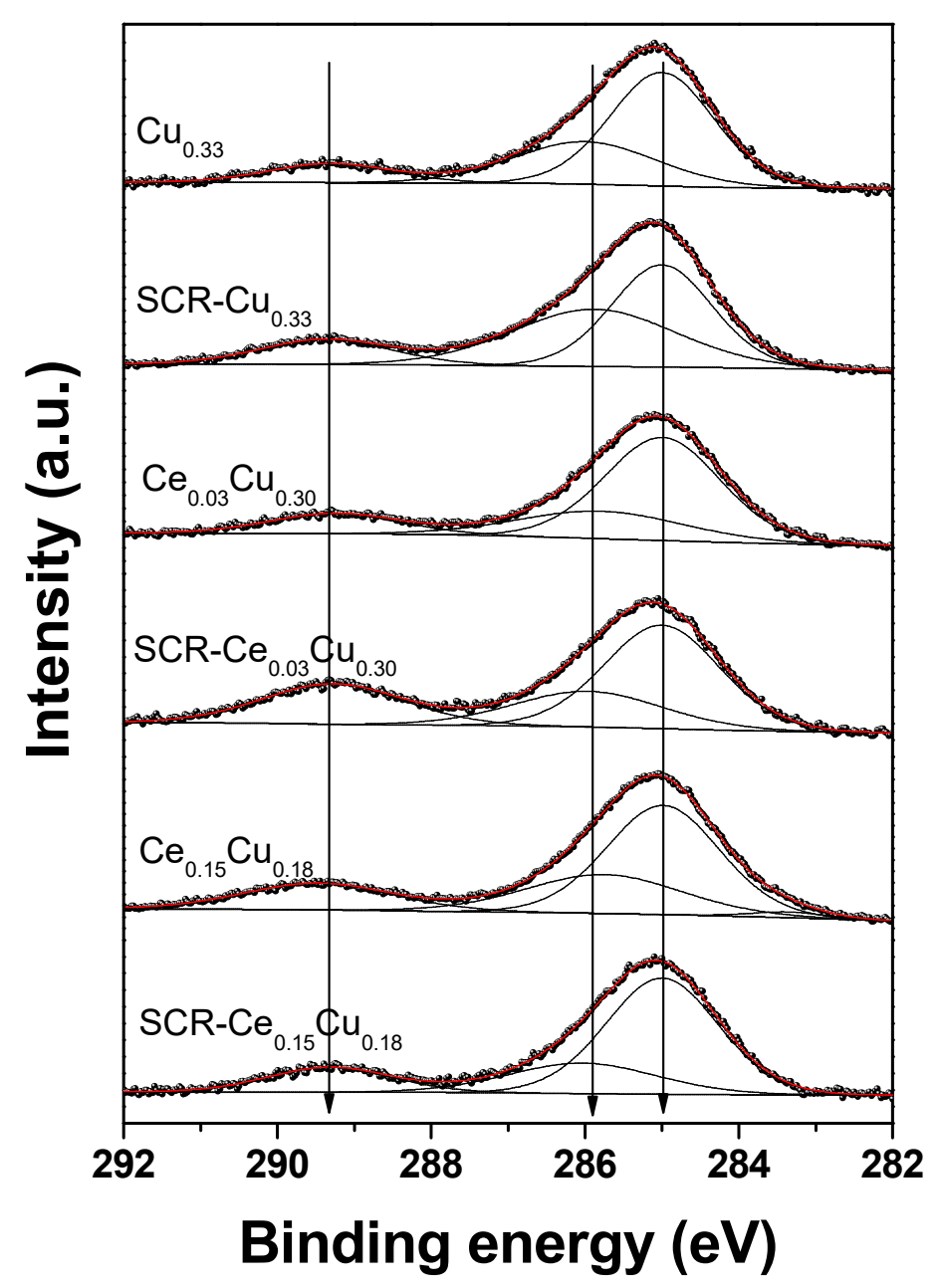

Figure 6. $\mathrm{C}$ 1s XPS spectra of $\mathrm{Cu}-\mathrm{Al}$ parent spinels and doped with cerium for fresh and used catalysts.

Three doublets were used to properly fit the $\mathrm{Cu} 2 \mathrm{p}$ spectra (Figure 7 and Table 4). The spin-orbit splittings of all doublets were in the range of $19.7-19.9 \mathrm{eV}$. The weakest doublet $(<5 \%)$ with $\mathrm{Cu} 2 \mathrm{p}_{3 / 2}$ $\mathrm{BE}$ values of $930.7-931.2 \mathrm{eV}$ is associated with the presence of reduced $\mathrm{Cu}^{+}$and/or $\mathrm{Cu}^{0}[12,19]$. Such a component can be related to the limited reduction of highly dispersed small copper particles under high-vacuum conditions or to the differential charging caused by some structural damages in the spinel structure. Some additional clue to distinguish between $\mathrm{Cu}^{+}$and $\mathrm{Cu}^{0}$ species can be drawn from the copper Wagner plot [20]. The kinetic energy of maximum of $\mathrm{Cu} \mathrm{L}_{3} \mathrm{M}_{45} \mathrm{M}_{45}$ Auger peak was read from the survey spectra, whereas binding energy of low-energy component from the $\mathrm{Cu}$ $2 \mathrm{p}$ high-resolution spectra. The copper Auger parameter for such contribution is below $1847.6 \mathrm{eV}$ for all measured samples. Thus, based on the copper Wagner plot, we can expect that a low-energy component is related more to $\mathrm{Cu}^{0}$ than $\mathrm{Cu}^{+}$[20]. However, one can point out that such a procedure is a major approximation only and results should be treated with caution. The most intense components origin from the octahedral $\mathrm{Cu}^{2+}(932.7-932.9 \mathrm{eV})$ [21] and tetrahedral $\mathrm{Cu}^{2+}$ species (933.9-934.5 eV) [19] in $\mathrm{Cu}-\mathrm{Al}$ spinel structure and/or $\mathrm{CuO}$ particles. The main photoelectron $\mathrm{Cu} 2 \mathrm{p}$ peaks are accompanied by strong shake-up satellites confirming that copper is present in all samples as $\mathrm{Cu}^{2+}$ species mainly. 


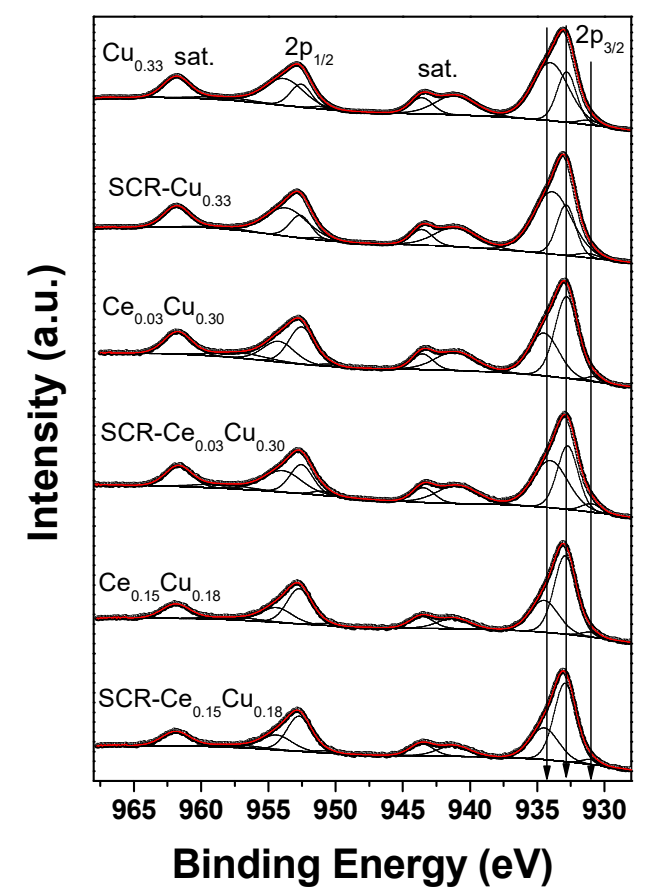

Figure 7. $\mathrm{Cu} 2 \mathrm{p}$ XPS spectra of $\mathrm{Cu}-\mathrm{Al}$ parent spinels and doped with cerium for fresh and used catalysts.

Table 4. Spectral fitting parameters for $\mathrm{Cu} 2 \mathrm{p}_{3 / 2}$ : binding energy (eV) and percentage of total area.

\begin{tabular}{cccc}
\hline Sample & Reduced $\mathrm{Cu}^{+}, \mathrm{Cu}^{0}$ & Octahedral Cu${ }^{2+}$ & Tetrahedral Cu${ }^{2+}$ \\
\hline \multirow{2}{*}{$\mathrm{Cu}_{0.33}$} & 931.2 & 932.8 & 934.0 \\
& $(2.8)$ & $(30.6)$ & $(66.6)$ \\
\hline \multirow{2}{*}{$\mathrm{SCR}-\mathrm{Cu}_{0.33}$} & 931.2 & 932.8 & 933.9 \\
& $(2.5)$ & $(27.6)$ & $(69.9)$ \\
\hline \multirow{2}{*}{$\mathrm{Ce}_{0.03} \mathrm{Cu}_{0.3}$} & 930.7 & 932.8 & 934.5 \\
& $(2.4)$ & $(58.1)$ & $(39.5)$ \\
\hline \multirow{2}{*}{$\mathrm{SCR}-\mathrm{Ce}_{0.03} \mathrm{Cu}_{0.30}$} & 931.0 & 932.7 & 934.0 \\
& $(5.2)$ & $(42.2)$ & $(52.6)$ \\
\hline \multirow{2}{*}{$\mathrm{Ce}_{0.15} \mathrm{Cu}_{0.18}$} & 931.0 & 932.9 & 934.5 \\
& $(3.2)$ & $(63.2)$ & $(33.6)$ \\
\hline \multirow{2}{*}{$\mathrm{SCR}-\mathrm{Ce}_{0.15} \mathrm{Cu}_{0.18}$} & 931.1 & 932.9 & 934.4 \\
& $(4.5)$ & $(49.4)$ & $(46.1)$ \\
\hline
\end{tabular}

In the parent $\mathrm{Cu}_{0.33}$ sample, copper was observed in the concentration twice lower than intended in the synthesis. The majority of $\mathrm{Cu}^{+2}$ species occupied tetrahedral sites in the amount ca. twice higher than found in our recent paper [22]. The ratio of tetrahedral to octahedral copper cations was close to typical of bulk partially inverse $\mathrm{CuAl}_{2} \mathrm{O}$ spinel (60:40) [23]. In copper-alumina systems, the spinel phase was the only one observed [11], and in the $\mathrm{Cu}_{0.33}$ sample, the reduced $\mathrm{Cu}^{+}$cations can occur in octahedrons which favor forming such species [23]. The SCR conditions resulted in a small decrease $(10 \%)$ in the presence of $\mathrm{Cu}^{2+}$ cations in octahedral sites as well as in the amount of reduced copper. Cerium addition caused a significant growth of the octahedral component mostly for $\mathrm{Ce}_{0.15} \mathrm{Cu}_{0.18}$ (over 63\%). It was shown [23] that $\mathrm{Cu}^{2+}$ ions in the octahedral positions are important in catalytic reactions due to undergoing $\mathrm{Cu}^{2+} \rightarrow \mathrm{Cu}^{+}$transitions. Moreover, the reduced copper is crucial in dissociative NO adsorption [11].

The Ce 3d XPS spectra of Ce-doped $\mathrm{Cu}-\mathrm{Al}$ catalysts as received and after SCR are presented in Figure 8. According to the common approach [24-27], Ce 3d spectra can be fitted with eight or ten components marked ' $v$ ' for Ce $3 d_{5 / 2}$ and ' $u$ ' for Ce $3 d_{3 / 2}$ multiplets. The multiplicity of these states 
comes from different $\mathrm{Ce} 4 \mathrm{f}$ level occupancies in the final state. Here, we have chosen 10-components approach; however, $\mathrm{v}_{0}$ and $\mathrm{u}_{0}$ peaks are difficult to resolve because the energy separation with $\mathrm{v}$ and u peaks is small. The peaks at $882.3(\mathrm{v}), 889.1\left(\mathrm{v}^{\prime \prime}\right)$, and $898.4 \mathrm{eV}\left(\mathrm{v}^{\prime \prime \prime}\right)$ as well as $900.9(\mathrm{u}), 907.6\left(\mathrm{u}^{\prime \prime}\right)$, and $916.7 \mathrm{eV}\left(\mathrm{u}^{\prime \prime \prime}\right)$ can be assigned to $\mathrm{Ce}^{4+}$, whereas $880.4\left(\mathrm{v}_{0}\right), 884.5\left(\mathrm{v}^{\prime}\right), 896.9\left(\mathrm{u}_{0}\right)$, and $902.9 \mathrm{eV}\left(\mathrm{u}^{\prime}\right)$ to $\mathrm{Ce}^{3+}$. The position of the $\mathrm{Ce}^{4+}$ reference line $\left(\mathrm{u}^{\prime \prime \prime}\right)$ was $916.7 \mathrm{eV}$ which is in perfect agreement with literature data [28]. The surface concentration of $\mathrm{Ce}^{3+}$ was estimated from the $\mathrm{Ce}^{3+} /\left(\mathrm{Ce}^{3+}+\mathrm{Ce}^{4+}\right)$ peak areas ratio [29]. Because $\mathrm{Ce} 3 \mathrm{~d}$ spectra are quite similar to reference $\mathrm{CeO}_{2}$ spectrum [30], a Ce ${ }^{3+}$ percentage of $29 \%\left(\mathrm{Ce}_{0.03}-\mathrm{SCR}\right), 43 \%\left(\mathrm{Ce}_{0.03}\right), 36 \%\left(\mathrm{Ce}_{0.15}-\mathrm{SCR}\right)$, and $30 \%\left(\mathrm{Ce}_{0.15}\right)$ found in our samples is very close to pure $\mathrm{CeO}_{2}$ [20], and is connected with the copper content on the surface as expected. However, these values are much higher than found in $\mathrm{Cu} / \mathrm{CeO}_{2}$ [19]. The presence of trivalent $\mathrm{Ce}^{3+}$ is closely related to the oxygen vacancies in the spinel structure, and as a result, influences the redox properties and catalytic performance of Ce-based systems. The vicinity of ceria is necessary for $\mathrm{Cu}^{+}$ions to take part in redox reactions. On the other hand, the presence of cerium retards the sintering of the $\mathrm{Cu}$ particles and ensures its good dispersion [11]. In the case of the $\mathrm{Ce}_{0.03} \mathrm{Cu}_{0.30}$ sample, the concentration of copper was retained at the surface, although its amount was decreased by $10 \%$ compared to the $\mathrm{Cu}_{0.33}$ sample. The same ratio of the surface copper amount to the intended $\mathrm{Cu}$ concentration was observed for the $\mathrm{Ce}_{0.15} \mathrm{Cu}_{0.18}$ sample. Copper covers preferentially ceria [11] like in the $\mathrm{Ce}_{0.15} \mathrm{Cu}_{0.18}$ sample, where the ratio of $\mathrm{Ce} / \mathrm{Cu}$ was twice lower than intended. The amount of reduced copper increased significantly after the SCR reaction, which could be the result of reducing conditions and the presence of cerium, because it was not observed for copper-aluminum oxide. During catalytic tests of Ce-containing samples, the concentration of copper in tetrahedral sites increased by about $25 \%$ at the cost of octahedral $\mathrm{Cu}$, not observed to such an extent for the $\mathrm{Cu}_{0.33}$ sample. This tetrahedral copper could form $\mathrm{CuO}$ [11] and pure $\mathrm{Al}_{2} \mathrm{O}_{3}$ spinel as observed in the $\mathrm{Ce}_{0.15} \mathrm{Cu}_{0.18}$ sample. In such copper-ceria-alumina systems, dissociative adsorption of $\mathrm{NO}$ and surface mobility of $\mathrm{N}$ atoms increase which can result in higher efficiency in SCR [11] observed for the $\mathrm{Ce}_{0.15} \mathrm{Cu}_{0.18}$ sample.

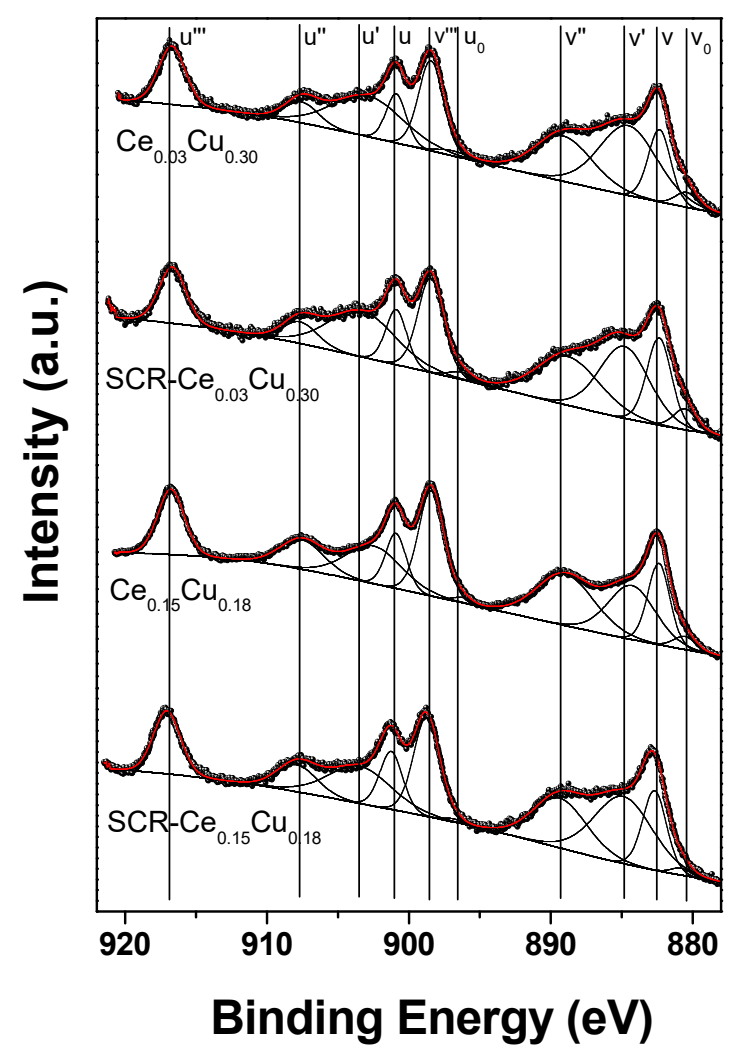

Figure 8. Ce $3 \mathrm{~d}$ XPS spectra of $\mathrm{Cu}-\mathrm{Al}$ spinels doped with cerium for fresh and used catalysts. 


\section{Materials and Methods}

Samples were obtained by coprecipitatation of metal nitrates with ammonium carbonate. The copper to aluminium ratio was equal to 1:2-typical of spinel compounds. The $1 \mathrm{M}$ solutions of copper $\left(\mathrm{Cu}\left(\mathrm{NO}_{3}\right)_{2} \cdot 3 \mathrm{H}_{2} \mathrm{O}\right)$ and aluminum $\left(\mathrm{Al}\left(\mathrm{NO}_{3}\right)_{3} \cdot 9 \mathrm{H}_{2} \mathrm{O}\right)$ nitrates were mixed and dropped into a beaker simultaneously with the $1 \mathrm{M}$ solution of $\left(\mathrm{NH}_{4}\right)_{2} \mathrm{CO}_{3}$ taken in a $20 \%$ excess to a stoichiometric amount. The solutions were added at a rate of $4 \mathrm{~mL} \mathrm{~min}^{-1}$ under stirring and the obtained precipitation was aged at $50{ }^{\circ} \mathrm{C}$ for one hour. Then, the solid was filtered with distilled water and dried overnight at room temperature. The sample was calcined at $900{ }^{\circ} \mathrm{C}$ for $6 \mathrm{~h}$. The sample was marked as $\mathrm{Cu}_{0.33}$. Next, samples were promoted with manganese or cerium and prepared analogously using $\mathrm{Ce}\left(\mathrm{NO}_{3}\right)_{3} \cdot 6 \mathrm{H}_{2} \mathrm{O}$ and $\mathrm{Mn}\left(\mathrm{NO}_{3}\right)_{2} \cdot 4 \mathrm{H}_{2} \mathrm{O}$ as substrates. The amount of copper was lowered and another metal was added to obtain the samples with the $\mathrm{Cu}: \mathrm{Ce}(\mathrm{Mn})$ ratio equal to 0.30:0.03 and 0.27:0.06, the sample where $\mathrm{Cu}: \mathrm{Ce}: \mathrm{Mn}$ was 0.27:0.03:0.03 was prepared as well. They were denoted as $\mathrm{Ce}_{0.03} \mathrm{Cu}_{0.30}$, $\mathrm{Ce}_{0.06} \mathrm{Cu}_{0.27}, \mathrm{Mn}_{0.03} \mathrm{Cu}_{0.30}, \mathrm{Mn}_{0.06} \mathrm{Cu}_{0.27}$, and $\mathrm{Ce}_{0.03} \mathrm{Mn}_{0.03} \mathrm{Cu}_{0.27}$. The samples with higher cerium concentrations-Cu:Ce equal to 0.24:0.09, 0.21:0.12, and 0.18:0.15-were synthesized and marked as $\mathrm{Ce}_{0.09} \mathrm{Cu}_{0.24}, \mathrm{Ce}_{0.12} \mathrm{Cu}_{0.21}$, and $\mathrm{Ce}_{0.15} \mathrm{Cu}_{0.18}$.

The samples were subjected to catalytic tests in selective catalytic reduction of $\mathrm{NO}$ with ammonia. The concentrations of $\mathrm{NO}$ and $\mathrm{NH}_{3}$ were equal to $800 \mathrm{ppm}$ and the oxygen concentration was $3.5 \%$. These reagents were diluted in helium and passed at a rate of $100 \mathrm{~mL} \mathrm{~min}^{-1}$ through a quartz reactor with $0.2 \mathrm{~g}$ of a catalyst. Its $0.25-1 \mathrm{~mm}$ fraction was placed on quartz wool. The concentrations of $\mathrm{NO}$ and $\mathrm{N}_{2} \mathrm{O}$ were measured in the temperature range of $150-450{ }^{\circ} \mathrm{C}$ at a step of $50{ }^{\circ} \mathrm{C}$ with the IR analyzers-serie $2020 \mathrm{~A} 0$, produced by ABB.

The crystallographic structure of the samples was determined with the powder X-ray diffraction. XRD patterns were recorded at $2 \theta$ angles from 10 to $90^{\circ}$, with a step of $0.013^{\circ}$ by a PANalytical-Empyrean diffractometer. As a radiation source, the copper lamp was used with $\lambda=1.5406 \AA$.

To perform the quantitative analysis of the metals contained in the materials, the XRF method was used. An EDX $3600 \mathrm{H}$ apparatus from Skyray Instruments with a tungsten lamp enabled probing with the depth larger than $50 \mu \mathrm{m}$.

The textural properties of samples were examined by the low temperature sorption of nitrogen. The isotherms were registered within the relative pressure range of 0-0.98 with a Gemini V 2.002380 (Micromeritics) analyzer. The specific surface area was measured using the BET method-SSA $\mathrm{BET}_{\text {. }}$. The total pore volume was assessed with the BJH model from the desorption branch.

$\mathrm{Cu}-\mathrm{Al}$ spinel $\left(\mathrm{Cu}_{0.33}\right)$ and the samples with minimum and maximum cerium concentrations $\left(\mathrm{Ce}_{0.03} \mathrm{Cu}_{0.30}\right.$ and $\left.\mathrm{Ce}_{0.15} \mathrm{Cu}_{0.18}\right)$ were subjected to surface analysis with X-ray Photoelectron Spectroscopy (XPS). The experiments were performed with a SES R4000 hemispherical analyzer (Gammadata Scienta) and non-monochromatic $\mathrm{MgK} \alpha \mathrm{X}$-ray radiation (1253.6 eV). The X-ray anode operated at $12 \mathrm{kV}$ and $15 \mathrm{~mA}$. For pass energy of $100 \mathrm{eV}$, the system resolution (FWHM) measured for the $\mathrm{Ag} 3 \mathrm{~d}_{5 / 2}$ line was $0.9 \mathrm{eV}$. The spectrometer calibration was conducted according to ISO 15472:2001. During the experiment, the pressure in the analysis chamber was close to $3 \times 10^{-10}$ mbar. Samples in the powder form were pressed into In foil and seated on a special holder. The analysis area was about $4 \mathrm{~mm}^{2}$ $(5 \times 0.8 \mathrm{~mm})$. The survey scans were obtained at pass energy of $200 \mathrm{eV}$ (with $250 \mathrm{meV}$ step), whereas the high-resolution spectra were obtained at a pass energy of $100 \mathrm{eV}$ (with $25 \mathrm{meV}$ step). The spectra deconvolution into individual components were performed with using the CasaXPS 2.3.19 software. We used a Shirley-type background algorithm and pseudo-Voigt line profiles (mixture of Gaussian and Lorentzian lines) with 70:30 variable proportions. The charging was corrected to the carbon $C 1 \mathrm{~s}$ line at $285.0 \mathrm{eV}$.

\section{Conclusions}

The precursor of mixed copper-aluminum oxide with the molar ratio 2:1 was obtained with the coprecipitation method. The sample crystallized in the inverse spinel structure. In subsequent samples, a part of copper- 0.03 and 0.06 - was substituted by cerium or manganese. Manganese was built 
into the spinel structure in contrast to $\mathrm{Ce}$ samples in which an additional $\mathrm{CeO}_{2}$ phase was detected. Since the $\mathrm{Ce}_{0.06} \mathrm{Cu}_{0.27}$ sample exhibited optimum catalytic efficiency, the amount of cerium was increased 2.5 times. The highly crystalline samples were mesoporous solids with a low specific surface area. The addition of cerium or/and manganese caused an increase in SSA. The maximum activity in SCR NO with ammonia within the broad temperature range was attained over the $\mathrm{Ce}_{0.15} \mathrm{Cu}_{0.18}$ sample. On the surface of this catalyst, well-dispersed copper was present mainly in octahedral sites, which was caused by the cerium presence. $\mathrm{Cu}$ concentration was twice higher than $\mathrm{Ce}$ and its amount was connected with the concentration of $\mathrm{Ce}^{3+}$. The high amount of this reduced cerium resulted from its interaction with the spinel. On the surface of this catalyst, copper was present mainly as copper oxide with a contribution of reduced copper, and oxygen occurred as lattice species. The concentration of reduced copper could influence this catalyst efficiency.

Author Contributions: Investigation, A.B., K.R., C.C., G.M., and J.G.; writing, A.B. and J.G. All authors have read and agreed to the published version of the manuscript.

Funding: This research was financed from Research Subvention AGH UST No 16.16.210.476.

Conflicts of Interest: The authors declare no conflict of interest.

\section{References}

1. Gómez-García, M.; Pitchon, V.; Kiennemann, A. Pollution by nitrogen oxides: An approach to NOx abatement by using sorbing catalytic materials. Environ. Int. 2005, 31, 445-467. [CrossRef] [PubMed]

2. Denisova, K.O.; Ilyin, A.A.; Rumyantsev, R.N.; Ilyin, A.P.; Volkova, A.V. Nitrous Oxide: Production, Application, and Protection of the Environment. Rus. J. Gen. Chem. 2019, 89, 46-54. [CrossRef]

3. Wu, L.; Chen, X.; Wei, W.; Liu, Y.; Wang, D.; Ni, B.-J. A Critical Review on Nitrous Oxide Production by Ammonia-Oxidizing Archaea. Environ. Sci. Technol. 2020, 54, 9175-9190. [CrossRef] [PubMed]

4. Montini, T.; Melchionna, M.; Monai, M.; Fornasiero, P. Fundamentals and Catalytic Applications of $\mathrm{CeO}_{2}$-Based Materials. Chem. Rev. 2016, 116, 5987-6041. [CrossRef] [PubMed]

5. Zhang, F.; Zhang, S.; Guan, N.; Schreier, E.; Richter, M.; Eckelt, R.; Fricke, R. NO SCR with propane and propene on Co-based alumina catalysts prepared by co-precipitation. Appl. Catal. B Environ. 2007, 73, 209-219. [CrossRef]

6. Han, L.; Cai, S.; Gao, M.; Hasegawa, J.-Y.; Wang, P.; Zhang, J.; Shi, L.; Zhang, D. Selective Catalytic Reduction of NOx with $\mathrm{NH}_{3}$ by Using Novel Catalysts: State of the Art and Future Prospects. Chem. Rev. 2019, 119, 10916-10976. [CrossRef] [PubMed]

7. Kumar, P.A.; Reddy, M.P.; Ju, L.K.; Hyun-Sook, B.; Phil, H.H. Low temperature propylene SCR of NO by copper alumina catalyst. J. Mol. Catal. A: Chem. 2008, 291, 66-74. [CrossRef]

8. Qi, F.; Xiong, S.; Liao, Y.; Dang, H.; Yang, S. A novel dual layer SCR catalyst with a broad temperature window for the control of NOx emission from diesel bus. Catal. Commun. 2015, 65, 108-112. [CrossRef]

9. Palčić, A.; Bruzzese, P.C.; Pyra, K.; Bertmer, M.; Góra-Marek, K.; Poppitz, D.; Pöppl, A.; Gläser, R.; Jabłońska, M. Nanosized Cu-SSZ-13 and Its Application in $\mathrm{NH}_{3}$-SCR. Catalysts 2020, 10, 506. [CrossRef]

10. Wu, X.; Meng, H.; Du, Y.; Liu, J.; Hou, B.; Xie, X. Insight into $\mathrm{Cu}_{2} \mathrm{O} / \mathrm{CuO}$ collaboration in the selective catalytic reduction of $\mathrm{NO}$ with $\mathrm{NH}_{3}$ : Enhanced activity and synergistic mechanism. J. Catal. 2020, 384, $72-87$. [CrossRef]

11. Fernández-García, M.; Rebollo, E.G.; Guerrero-Ruiz, A.; Conesa, J.; Soria, J.; Luque, R. Influence of Ceria on the Dispersion and Reduction/Oxidation Behaviour of Alumina-Supported Copper Catalysts. J. Catal. 1997, 172, 146-159. [CrossRef]

12. Ponmudi, S.; Sivakumar, R.; Sanjeeviraja, C.; Gopalakrishnan, C.; Jeyadheepan, K. Facile fabrication of spinel structured n-type $\mathrm{CuAl}_{2} \mathrm{O}_{4}$ thin film with nano-grass like morphology by sputtering technique. Appl. Surf. Sci. 2019, 483, 601-615. [CrossRef]

13. Anderson, J.; Fierro, J. Bulk and Surface Properties of Copper-Containing Oxides of the General Formula $\mathrm{LaZr}_{1-\mathrm{x}} \mathrm{Cu}_{\mathrm{x}} \mathrm{O}_{3}$. J. Solid State Chem. 1994, 108, 305-313. [CrossRef]

14. Ertl, G.; Hierl, R.; Knözinger, H.; Thiele, N.; Urbach, H. XPS study of copper aluminate catalysts. Appl. Surf. Sci. 1980, 5, 49-64. [CrossRef] 
15. Paparazzo, E. XPS studies of damage induced by X-ray irradiation on $\mathrm{CeO}_{2}$ surfaces. Surf. Sci. 1990, 234, L253-L258. [CrossRef]

16. Sarma, D.; Rao, C. XPES studies of oxides of second- and third-row transition metals including rare earths. J. Electron Spectrosc. Relat. Phenom. 1980, 20, 25-45. [CrossRef]

17. Turner, N.H.; Single, A.M. Determination of peak positions and areas from wide-scan XPS spectra. Surf. Interface Anal. 1990, 15, 215-222. [CrossRef]

18. Han, M.; Wang, Z.; Xu, Y.; Wu, R.; Jiao, S.; Chen, Y.; Feng, S. Physical properties of $\mathrm{MgAl}_{2} \mathrm{O}_{4}, \mathrm{CoAl}_{2} \mathrm{O}_{4}$, $\mathrm{NiAl}_{2} \mathrm{O}_{4}, \mathrm{CuAl}_{2} \mathrm{O}_{4}$, and $\mathrm{ZnAl}_{2} \mathrm{O}_{4}$ spinels synthesized by a solution combustion method. Mater. Chem. Phys. 2018, 215, 251-258. [CrossRef]

19. Severino, F.; Brito, J.L.; Laine, J.M.; Fierro, J.; Agudo, A. Nature of Copper Active Sites in the Carbon Monoxide Oxidation on $\mathrm{CuAl}_{2} \mathrm{O}_{4}$ and $\mathrm{CuCr}_{2} \mathrm{O}_{4}$ Spinel Type Catalysts. J. Catal. 1998, 177, 82-95. [CrossRef]

20. NIST XPS Database. Available online: https://srdata.nist.gov/xps/ (accessed on 28 November 2020).

21. Shen, Y.; Guo, M.; Xia, X.; Shao, G. Role of materials chemistry on the electrical/electronic properties of $\mathrm{CuO}$ thin films. Acta Mater. 2015, 85, 122-131. [CrossRef]

22. Białas, A.; Kuśtrowski, P.; Dudek, B.; Piwowarska, Z.; Wach, A.; Michalik, M.; Kozak, M. Copper-aluminum oxide catalysts for total oxidation of toluene synthesized by thermal decomposition of co-precipitated precursors. Thermochim. Acta 2014, 590, 191-197. [CrossRef]

23. Bechara, R.; Aboukai's, A.; Bonnelle, J.-P. X-Ray Photoelectron Spectroscopic Study of a Cu-AI-0 Catalyst under H, or CO Atmospheres. J. Chem. Soc. Faraday Trans. 1993, 89, 1257-1262. [CrossRef]

24. Konsolakis, M.; Ioakeimidis, Z. Surface/structure functionalization of copper-based catalysts by metal-metal interaction. Appl. Surf. Sci. 2014, 320, 244-255. [CrossRef]

25. Ramana, S.; Rao, B.G.; Venkataswamy, P.; Rangaswamy, A.; Reddy, B.M. Nanostructured Mn-doped ceria solid solutions for efficient oxidation of vanillyl alcohol. J. Mol. Catal. A Chem. 2016, 415, 113-121. [CrossRef]

26. Romeo, M.; Bak, K.; El Fallah, J.; Le Normand, F.; Hilaire, L. XPS Study of the reduction of cerium dioxide. Surf. Interface Anal. 1993, 20, 508-512. [CrossRef]

27. Pappacena, A.; Rancan, M.; Armelao, L.; Llorca, J.; Ge, W.; Ye, B.; Lucotti, A.; Trovarelli, A.; Boaro, M. New Insights into the Dynamics That Control the Activity of Ceria-Zirconia Solid Solutions in Thermochemical Water Splitting Cycles. J. Phys. Chem. C 2017, 121, 17746-17755. [CrossRef]

28. Damyanova, S.; Perez, C.; Schmal, M.; Bueno, J. Characterization of ceria-coated alumina carrier. Appl. Catal. A Gen. 2002, 234, 271-282. [CrossRef]

29. Artiglia, L.; Orlando, F.; Roy, K.; Kopelent, R.; Safonova, O.V.; Nachtegaal, M.; Huthwelker, T.; Van Bokhoven, J.A. Introducing Time Resolution to Detect Ce3+ Catalytically Active Sites at the Pt/CeO2 Interface through Ambient Pressure X-ray Photoelectron Spectroscopy. J. Phys. Chem. Lett. 2017, 8, 102-108. [CrossRef]

30. Gurgul, J.; Rinke, M.T.; Schellenberg, I.; Pöttgen, R. The antimonide oxides REZnSbO and REMnSbO $(\mathrm{RE}=\mathrm{Ce}, \mathrm{Pr}) ;$ An XPS study. Solid State Sci. 2013, 17, 122-127. [CrossRef]

Publisher's Note: MDPI stays neutral with regard to jurisdictional claims in published maps and institutional affiliations.

(C) 2020 by the authors. Licensee MDPI, Basel, Switzerland. This article is an open access article distributed under the terms and conditions of the Creative Commons Attribution (CC BY) license (http://creativecommons.org/licenses/by/4.0/). 